\title{
Age-gender structure of Yugoslav population in Vojvodina Province
}

\author{
Tamara Kovačević, \\ Milka Bubalo Živković, Anđelija Ivkov'
}

\begin{abstract}
Analysis and comparison of the overall Yugoslav population according to the Censuses are elaborated in this paper. Identification of tendencies in age structure of Yugoslav population is very important because it represents one of age patterns among the population of Vojvodina. Different parameters of ageing are compared (e.g. median age, ageing index, etc) by applying statistical and mathematical methods. Influences of demographic transition on Yugoslav population in Vojvodina Province are discussed in this paper. Important facts on Yugoslav population in Vojvodina Province are achieved in this paper.
\end{abstract}

Key words: age structure, Yugoslavs, demographic transition, Vojvodina Province

\footnotetext{
University of Novi Sad, Faculty of Science and Mathematics, Department of Geography, Tourism and Hotel Management, Trg Dositeja Obradovica 3, tel. +38121450602, fax. +38121450105, snstamara@yahoo.com
}

\section{Introduction}

Who is a Yugoslav? A Yugoslav was an ethnic term used by some people who neither had strong ethnic identity nor wished to express it, but who still had patriotic feelings for the country and did not want their ethnicity to be recorded as undeclared.

In the late $19^{\text {th }}$ and early $20^{\text {th }}$ century, the term "Yugoslav" was used as a synonym for "South Slav", especially to denote Slavic population in Austria-Hungary. After the Worl War I, in 1918, when South Slavic lands were united in the Kingdom of Serbs, Croats and Slovenes, the term Yugoslav was used to refer to any of its inhabitants, particularly of Southern Slavic origin. In order to resolve a deep political crisis brought on by ethnic tensions by assuming dictatorial powers, the King Alexander renamed the country into the Kingdom of Yugoslavia and officially pronounced a single Yugoslav nation with three tribes in 1929. The Yugoslav ethnic designation was thus for a time imposed on all South Slavs in Yugoslavia. Changes in Yugoslav politics after the King Alexander's death in 1934 ended this policy, but the designation continued to be used by some people. In the second part of 2 oth century, people often declared as Yugoslavs. After the break up of the Socialist Federal Republic of Yugoslavia, most Yugoslavs declared themselves as Serbs, Croats, Bosnian, Slovenes, Macedonians, Montenegrins etc, but the designation still continued to be used. In the 2002 census, 49,881 inhabitants of vojvodina declared themselves as Yugoslavs.

Today, Yugoslav population represents $2.5 \%$ of the population of Vojvodina and only $1.1 \%$ of the population of Serbia. $61.8 \%$ of the overall number of Yugoslav population in Serbia lives in Vojvodina. The greatest concentration is in the biggest towns in Vojvodina (Novi Sad, Subotica and Sombor) (Ministry of Human and Minority Rights, 2004). Since Vojvodina is a multiethnic area, the Yugoslav nation was selected for this research.

\section{The number of Yugoslav population in Vojvodina Province}

Big changes in the number of Yugoslav population in Vojvodina Province are recorded. Past and present declaration as Yugoslav in Vojvodina Province can be observed through their age structure. Some people consider Yugoslavs an artificial nation. In their short history they experienced alternations in the population number (appeared, increased, culminated and decreased). Their age structure answers the following question: Does this nation have a future? Parameters of age structure can also show the degree of influence of demographic transition on the Yugoslav population.

Yugoslav nation was established for the first time in the 1961 census, when only about three thousand people declared as Yugoslavs. They represented only $0.2 \%$ in the population of Vojvodina. Moreover, there was a growing tendency of declaring as Yugoslavs, especially among the Serbs. The number of Yugoslavs increased more than 14 times as recorded in the 1971 census. Significant growth was recorded in 1981 (Table 1). The Law from 1974 very insisted on the development of multiethnic structure of the population Vojvodina. This resulted in the fact that more and more people started to feel like Yugoslavs. According the 1991census, the largest number of Yugoslavs was recorded in Vojvodina. Their share was $8.7 \%$ of the overall population of Vojvodina (Republic Office of Statistics, 2003). According to the last census, the number of Yugoslavs decreased almost 3.5 times (Graph 1).

In 1961 and 1971, there were more males in the Yugoslav population, but later the situation changed. However, differences between the share of males and females were not significant.

\section{Age structure}

According to Sundbarg's typology, the present Yugoslav population has regressive type of age structure (Djurdjev, 1996). However, significant changes in their age structure are the result of changes in the number of overall population. Generally, 
Table 1 Changes in the number of Yugoslav population in Vojvodina 1961-2002

\begin{tabular}{|l|r|r|r|r|r|r|}
\hline Censuses & \multicolumn{1}{|c|}{$\begin{array}{c}\text { Yugoslav } \\
\text { population }\end{array}$} & \multicolumn{1}{c|}{$\begin{array}{c}\text { Males } \\
(\mathbf{\%})\end{array}$} & $\begin{array}{c}\text { Females } \\
\mathbf{( \% )}\end{array}$ & $\begin{array}{c}\text { Share in the } \\
\text { population of } \\
\text { Vojvodina }\end{array}$ & $\begin{array}{c}\text { Index } \\
\text { increase } \\
(\mathbf{1 9 6 1 )}\end{array}$ & $\begin{array}{r}\text { Chain } \\
\text { index }\end{array}$ \\
\hline 1961 & 3,174 & 55.1 & 44.9 & 0.2 & 100.0 & - \\
\hline 1971 & 46,928 & 50.3 & 49.7 & 2.4 & $1,478.5$ & $1,478.5$ \\
\hline 1981 & 167,215 & 48.7 & 51.3 & 8.2 & $5,268.3$ & 356.3 \\
\hline 1991 & 174,295 & 47.2 & 52.8 & 8.7 & $5,491.3$ & 104.2 \\
\hline 2002 & 49,881 & 47.1 & 52.9 & 2.5 & $1,571.6$ & 28.6 \\
\hline
\end{tabular}

Source: (Kocsis, Kicošev, 2004), (Republic Statistical Office, 2003)

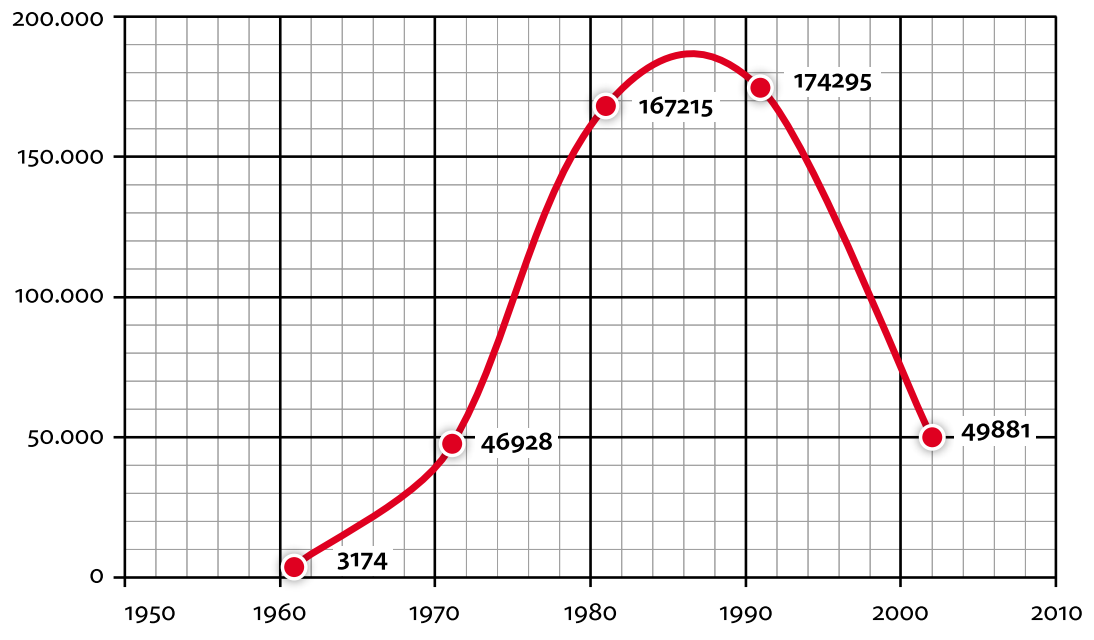

Census

Graph 1 Changes in the number of Yugoslav population in Vojvodina, According to the Censuses between 1961-2002

the type of age structure was changed from rapid and slow to negative growth. Such evolution of the change was expected. Similar evolution occurred among the overall population of Vojvodina (Table 2). In 1961, the share of young people was $37.1 \%$. In the period 1971-1991, the number of young people was between $26-30 \%$. According to the latest census, this value decreased to $18.6 \%$. More than half of the population (48-58\%) belongs to the biggest population category (15-49). In the long period (1961-1991), the share of the oldest cohort (aged 50 and above) was less than $20 \%$ in the overall population. In 2002, this share was more than $1 / 4$ in the overall population.

Rosset's model was based on the share of cohort 60 and above in the overall population. In 1971, according to this model, the Yugoslav population belonged to the "demographic youth" type. Mostly, they were on the threshold of the old age. Demographic situation was the worst in 2002. According to the census and Rosset's model, the Yugoslav population "is in the process of ageing" (Kicošev, Golubović, 2004). After 1971, the share of the cohort 60 and above was more than $12 \%$ in the population of Vojvodina. Thus, it belonged to the "demographic old" population type. Therefore, the overall population of Vojvodina is older than the Yugoslav population in Vojvodina.

Graphical presentation of the age groups would be the pyramid. Age pyraof a population according to gender and age, which means that their comparison is possible (Breznik, 1980). The five-year age groupings on the y-axis allow the pyramid to vividly reflect long term trends in the birth and death rates but also reflect shorter term baby-booms, wars, and epidemics.

The pyramid of 1961 was the first pyramid where the Yugoslav population in Vojvodina was identified, because it was the 1961 Census when the term was first officially recorded (graph 2). At that time, it was a rather small population. It was almost a pyramid with a rapid growth or of progressive type. In that decade the growth rate was still high in Vojvodina. Numerous families with a lot of children from the mountain regions in Bosnia, Montenegro, Macedonia, etc. immigrated to Vojvodina after World War II. They felt like Yugoslavs. Anomaly in the pyramid was perceived within the population group, which was born either during World War II or 10 years before it. The size of the oldest cohort was unexpectedly large. In 1961, the participants of World War II and their children formed the largest part of Yugoslav population in Vojvodina. Those were the first evidences of Yugoslav population in history.

Between 1961 and 1971, the number of Yugoslav population increased almost 15 times. Therefore, the comparison of these census data is not justified. This grow was not the result of growth rate. In multiethnic area, such as Vojvodina, many people wished to express their sentiments on the irrelevance of the ethnic background.

Age-gender pyramid showed the tendency of slow growth or stationary type. There were more males compared to the number of females. The exception was annotated within the age group of 45-49. The share of age groups $15-19$ and 20-24 was the highest. These generations were born after

Table 2 Age structure of Yugoslav population (in \%), According to Censuses 1961-2002

\begin{tabular}{|c|r|r|r|r|r|}
\hline \multirow{2}{*}{$\begin{array}{c}\text { Age structure of the overall } \\
\text { population of Vojvodina }\end{array}$} & \multicolumn{5}{|c|}{ Censuses } \\
\cline { 2 - 6 } & $\mathbf{1 9 6 1}$ & $\mathbf{1 9 7 1}$ & \multicolumn{1}{|c|}{$\mathbf{1 9 8 1}$} & \multicolumn{1}{|c|}{$\mathbf{1 9 9 1}$} & \multicolumn{1}{c|}{$\mathbf{2 0 0 2}$} \\
\hline $0-14$ & 26.6 & 21.2 & 19.9 & 19.2 & 15.9 \\
\hline $15-49$ & 50.2 & 54.6 & 51.4 & 48.5 & 49.4 \\
\hline $50+$ & 23.1 & 24.1 & 28.7 & 32.3 & 34.8 \\
\hline Total & 100.0 & 100.0 & 100.0 & 100.0 & 100.0 \\
\hline $60+$ & 11.9 & 14.8 & 15.2 & 18.7 & 21.9 \\
\hline Age structure of Yugoslav & & \multicolumn{5}{|c|}{ Censuses } \\
\hline population & $\mathbf{1 9 6 1}$ & $\mathbf{1 9 7 1}$ & $\mathbf{1 9 8 1}$ & $\mathbf{1 9 9 1}$ & $\mathbf{2 0 0 2}$ \\
\hline 0-14 & 37.1 & 26.5 & 29.2 & 28.9 & 18.6 \\
\hline $15-49$ & 48.0 & 58.3 & 52.6 & 54.1 & 56.1 \\
\hline $50+$ & 14.9 & 15.1 & 18.2 & 17.0 & 25.3 \\
\hline Total & 100.0 & 100.0 & 100.0 & 100.0 & 100.0 \\
\hline $60+$ & 8.0 & 7.5 & 8.4 & 9.6 & 13.7 \\
\hline
\end{tabular}

Source: (Republic Statistical Office, 2003), (Federal Statistical Office, 1970), (Federal Statistical Office, 1974), (Provincial Statistical Office, 1982) and (Federal Statistical Office, 1993) 
World War II and since that their ethnic orientation was Yugoslavs. The pyramid showed that the newborns were very often noted as Yugoslavs. Generation groups born between two World Wars showed similar tendencies in overall population (graph 3).

According to 1981 Census, the number of Yugoslav population increased more than 3 times. It was politically more appropriate to be a Yugoslav, since Yugoslavia was a modern and perspective European country. Some minor nationalities, such as Bunjevci, did not have strong national affiliations. Also a Bunjevac was not officially recognized as a national minority until 2002. The relation between males and females has changed. Males were dominant in age groups $35-39$ and 40-44, and in the youngest age cohorts 0-4, 5-9 and 10-14. Females were dominant in other nine cohorts. Certain correlations between the pyramids are possible. For example, the generations which were born between two World Wars, in the Kingdom of Yugoslavia, kept the same form in the pyramid (graph 4). In addition, their share in overall was predictable. However, the 1981 pyramid had an unusual form. It did not belong to progressive type, since the share of age categories 1014, 15-19, 20-24 was smaller than the others. Those were the generations which were born during the time when being a Yugoslav was not as politically appropriate as in the 1980s. The fact that not a single pyramid resembled the pyramids of the population of Vojvodina was the most interesting. The share of generations which were born or participated in the two World Wars was reduced.

According to the 1991 Census, it was the period with the highest number of Yugoslav population in Vojvodina. Between 1981 and 1991, the number of Yugoslav population increased symbolically. In certain decades, mixed marriages were common. Some families of different ethnic backgrounds preferred not to declare their ethnicity. But, it was not so politically appropriate to be a Yugoslav. That thesis supported the reduced number of the newborns in the group o-4 (graph 5). As in the two previous pyramids, this pyramid is divided into two parts. The upper part had the smaller share in the total number. It was a part with generations which were born prior to World War II. The lower part is lager and shows numerous younger age groups. The differences between the other age categories are reduced. The pyramids show the tendency of slow growth or stationary form. Females are dominant in all age groups except in the youngest ones (o4 and 5-9). That was the time when the crisis started and it was not possible to predict the results of the following census.

The last decade of 1990 os was the worst one after the end of World War II. Unsta-
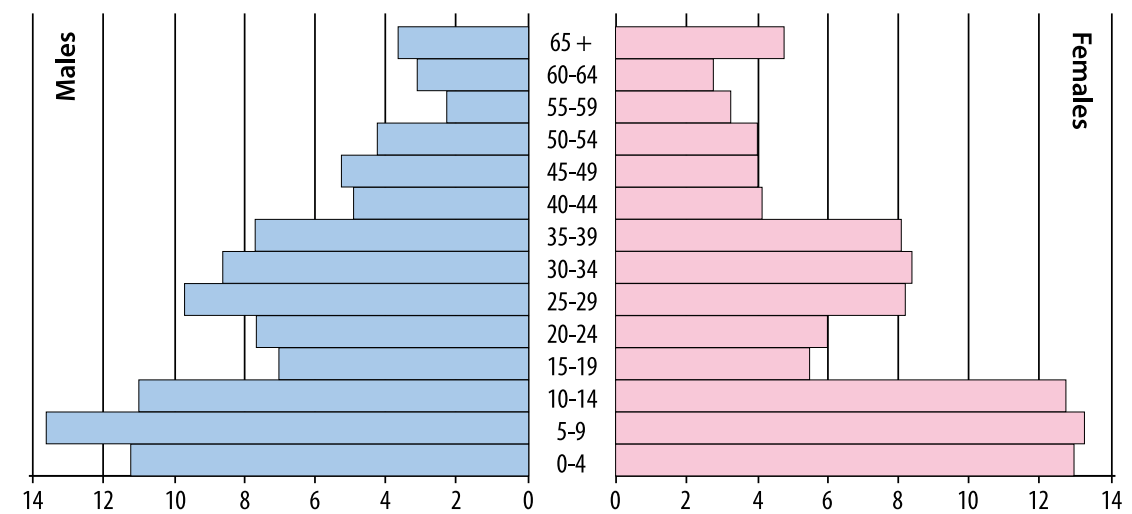

Graph 2 Age structure of Yugoslav population in Vojvodina (in \%), according to Census 1961
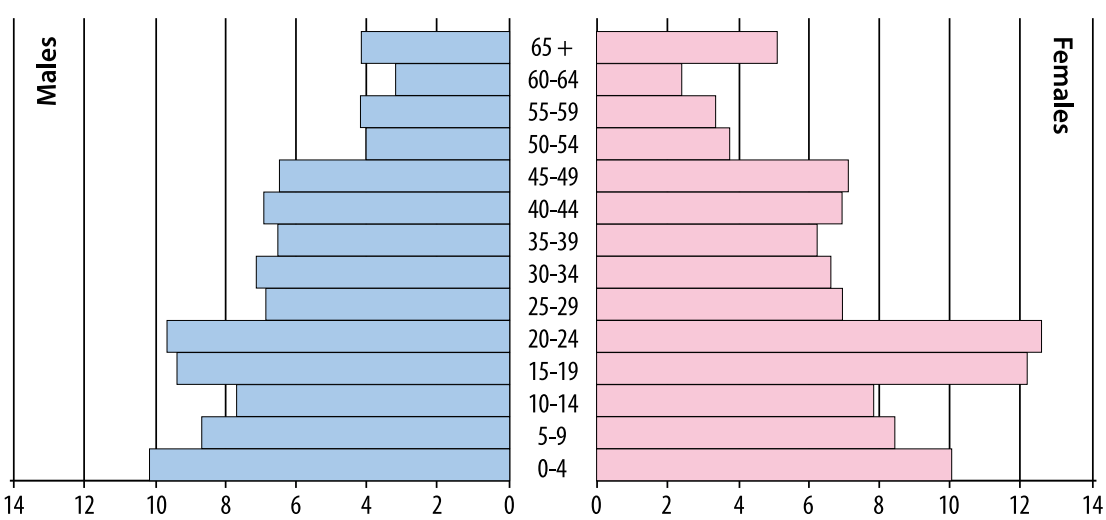

Graph 3 Age structure of Yugoslav population in Vojvodina (in \%), according to Census 1971
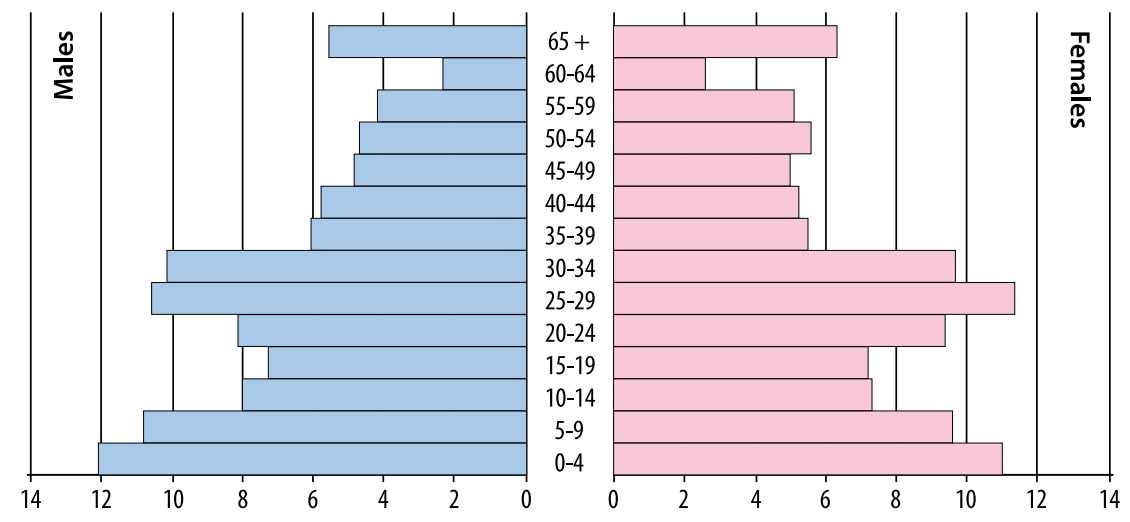

Graph 4 Age structure of Yugoslav population in Vojvodina (in \%), according to Census 1981
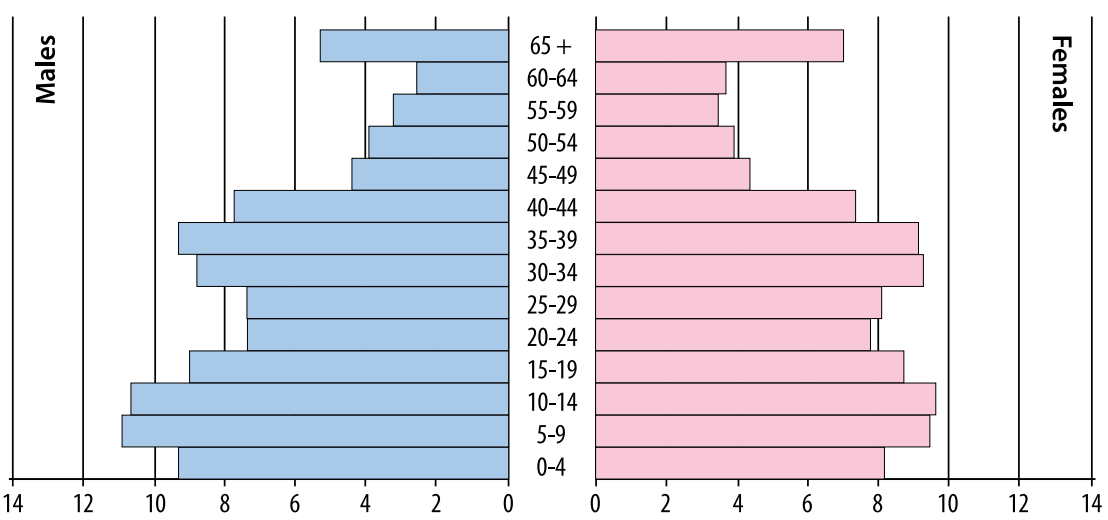

Graph 5 Age structure of Yugoslav population in Vojvodina, according to Census 1991 

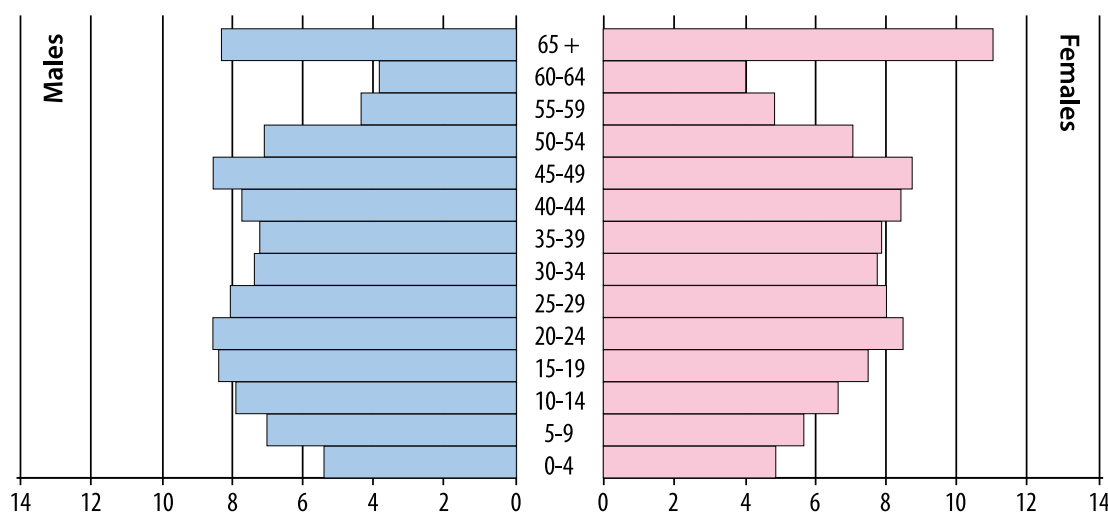

Graph 6 Age structure of Yugoslav population in Vojvodina (in \%), according to Census 2002

Table 3 Average age of Yugoslav population in Vojvodina, according to Censuses 1961-2002

\begin{tabular}{|c|c|c|c|c|c|c|}
\hline & Year & 1961 & 1971 & 1981 & 1991 & $2002^{*}$ \\
\hline \multirow{2}{*}{ Total } & Vojvodina population & 32.2 & 34.4 & 36.1 & 37.7 & 39.8 \\
\hline & Yugoslav population & 27.4 & 29.2 & 29.7 & 30.2 & 35.6 \\
\hline \multirow{2}{*}{ Male } & Vojvodina population & 31.2 & 35.4 & 34.9 & 39.0 & 38.3 \\
\hline & Yugoslav population & 26.9 & 29.3 & 30.4 & 31.0 & 34.3 \\
\hline \multirow{2}{*}{ Female } & Vojvodina population & 33.2 & 33.3 & 37.4 & 36.3 & 41.3 \\
\hline & Yugoslav population & 27.9 & 29.1 & 29.0 & 29.3 & 36.8 \\
\hline
\end{tabular}

Source: (Republic Statistical Office, 2003), (Federal Statistical Office, 1970), (Federal Statistical Office, 1974), (Provincial Statistical Office, 1982) and (Federal Statistical Office, 1993)

* Data for 2002 are taken from the following source: Republic Statistical Office, 2003

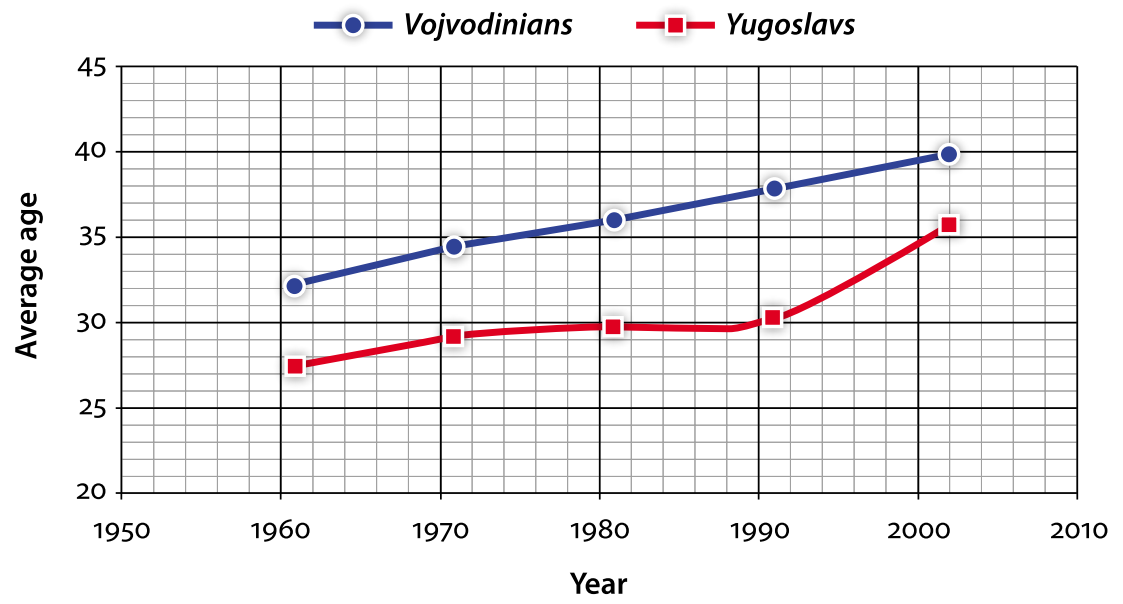

Graph 7 Average age of Yugoslav population in Vojvodina, according to Censuses 1961-2002

Table 4 Median age of Yugoslav population in Vojvodina, according to censuses 1961-2002

\begin{tabular}{|l|r|r|r|r|r|}
\hline \multicolumn{7}{|c|}{1961} & 1971 & 1981 & 1991 & \multicolumn{1}{c|}{2002} \\
\hline Vojvodina population & 30.0 & 38.2 & 34.6 & 37.4 & 40.3 \\
\hline Total & 28.9 & 32.1 & 33.2 & 36.0 & 38.6 \\
\hline Males & 31.2 & 34.8 & 36.4 & 38.8 & 42.0 \\
\hline Females & 24.8 & 24.8 & 27.3 & 28.1 & 34.7 \\
\hline Yugoslav population \\
\hline Total & 24.7 & 25.3 & 26.9 & 27.1 & 33.1 \\
\hline Males & 24.8 & 24.5 & 27.6 & 28.9 & 36.0 \\
\hline Females &
\end{tabular}

Source: (Republic Statistical Office, 2003), (Federal Statistical Office, 1970), (Federal Statistical Office, 1974), (Provincial Statistical Office, 1982) and (Federal Statistical Office, 1993) ble political situation, wars in the neighboring countries, economic crisis, embargo, NATO aggression, etc. occurred in only ten-year period. The borders changed and certain Yugoslav Republics became separate countries. The territory of $\mathrm{Yu}$ goslavia was reduced more than 2.5 times. Ethnic feelings awakened and flourished. A lot of people changed their ethnic declaration. In 2002, the number of Yugoslav population in Vojvodina decreased almost 3.5 times. Therefore, the comparison of the 2002 pyramid with other pyramids is not justified. This pyramid is of regressive type (graph 6). Females express higher level of nostalgia towards the Former Yugoslavia. There are more males only in the age group 20-24.

\section{Average Age}

From 1961 the population of Vojvodina has had higher average age than Yugoslav population in Vojvodina, but its increase was relatively stable. From 1961 to 2002 the average age of Yugoslav population increased more than 8 years, but between the two latest Censuses it increased more than 5 years (graph 7). It is the result of the decrease in overall Yugoslav population in 2002. Younger population easier changes their ethnicity. In 1961 and 2002, average age of male Yugoslav population was smaller than that of female.

Population average age is very important because of its reproductive ability. It is known that female reproductive period ends at 45. According to 2002 Census, the average age of women in Vojvodina is alarming. In 2002, Yugoslav women were at the level as women in Vojvodina in 1991 (table 3). The newest age pyramid introduces the growth of average age of Yugoslav women in future.

\section{Median age}

Median age is reliable and frequently used parameter when compared to average age. Therefore, extreme values of the five-year age groupings did not influence the average age (Djurdjev, 1996). From 1961 to 2002, the median age of Yugoslav population is constantly increasing. However, it was slow compared to the population of Vojvodina.

In 1961 and 1971, the median age of Yugoslav population in Vojvodina was stable (24.8). After that period, it started to increase. Between 1991 and 2002, the median age increased more than 6 years. The reason for that is the decrease in the overall number of Yugoslav population. According to 2002 Census, the values of median age of Yugoslav population in Vojvodina correspond to the values of median old age of the population of Vojvodina in 1981 (table 4).

Median age for male Yugoslav population increased more slowly compared 
to female Yugoslav population (graph 8). Similar situation is recorded among the population in Vojvodina, although with higher values.

\section{The Old Age Index}

If the old age index is less then 0.4, population is considered young, whereas higher values indicate old age population (Rančić, 1980). For the population of Vojvodina, the limit of 0.4 was exceeded in 1971. Therefore, the population of Vojvodina indicates the first signs of ageing (table 5).

In the period 1961-1991, Yugoslav population in Vojvodina was considered young. However, the old age index grew slowly. In 2002, a significant change occurred, when the old age index doubled (graph 9). This is the proof that changes among Yugoslav population are not naturally caused.

\section{Coefficients of old and young age}

Coefficients of old age directly show negative process of ageing within certain population. The age process includes the increase in the share of population aged 60 and above. When the number exceeds $120 \%$, the population starts to be considered demographically old (Kicošev, Golubović, 2004). According to that parameter, the population of Vojvodina has been in the process since 1961. The Yugoslav population in Vojvodina entered the process of ageing in 2002 (table 6). In addition, its coefficient was almost 1.6 times lower than the coefficient of the population of Vojvodina in 2002.

Coefficient of young age of the population of Vojvodina has slowly decreased. In the case of Yugoslav population, the situation seems to be uncommon, however, it also showed decreasing tendency. In 1961, it was 1.6 time higher than in 2002. According to the censuses 1971-1991, it the values were unchanged (graph 10). Significant change occurred between the latest two censuses. It could have been caused by demographic transition.

\section{Conclusion}

As a nation, Yugoslavs in Vojvodina were recorded in 1961. It was about 30 years after the constitution of the first Yugoslavia, the Kingdom of Yugoslavia. During certain periods (1971-1991), it was intellectually reasonable and politically appropriate to be a Yugoslav. This part of the population of Vojvodina was considered relatively young. Foreign and domestic policies strongly influenced the young part of the population. Consequently, older Yugoslavs rarely changed their ethnicity. The influences of demographic transition are present, but their importance considering Yugoslavs in Vojvodina is of secondary value. The analysis of age structure did not even recognize the influence of demographic transition

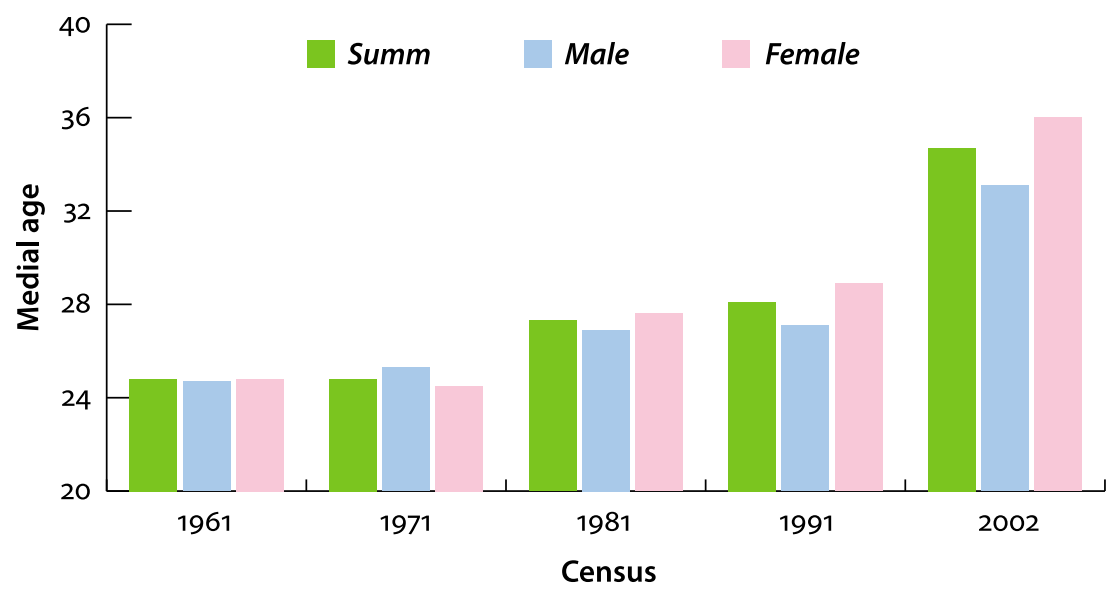

Graph 8 Median age of Yugoslav population in Vojvodina, according to censuses 1961-2002

Table 5 Age index of Yugoslav population in Vojvodina, according to censuses 1961-2002

\begin{tabular}{|l|r|r|r|r|r|}
\hline Censuses & \multicolumn{1}{|c|}{$\mathbf{1 9 6 1}$} & \multicolumn{1}{c|}{$\mathbf{1 9 7 1}$} & \multicolumn{1}{c|}{$\mathbf{1 9 8 1}$} & \multicolumn{1}{c|}{$\mathbf{1 9 9 1}$} & \multicolumn{1}{c|}{$\mathbf{2 0 0 2}$} \\
\hline Vojvodina population & 0.36 & 0.49 & 0.57 & 0.73 & 0.97 \\
\hline Yugoslav population & 0.18 & 0.19 & 0.23 & 0.25 & 0.52 \\
\hline
\end{tabular}

Source: (Republic Statistical Office, 2003), (Federal Statistical Office, 1970), (Federal Statistical Office, 1974), (Provincial Statistical Office, 1982) and (Federal Statistical Office, 1993)a

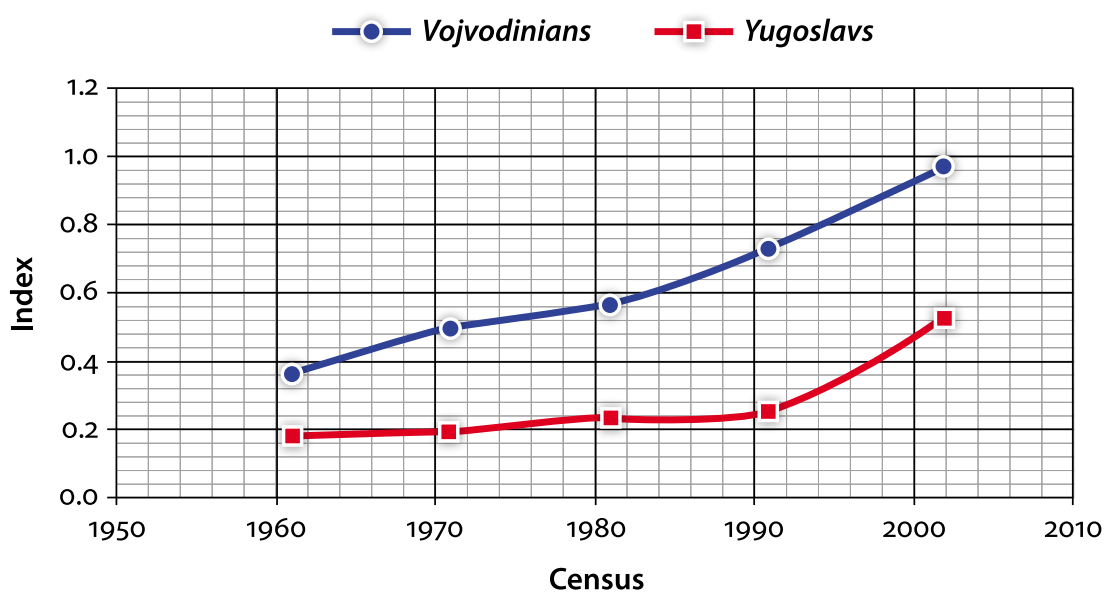

Graph 9 Age index of Yugosla population in Vojvodina, according to censuses 1961-2002

Table 6 Coefficients of old and young age of Yugoslav population in Vojvodina (in \%o), according to censuses 1961-2002

\begin{tabular}{|l|r|r|r|r|r|}
\hline Census & \multicolumn{1}{|l|}{$\mathbf{1 9 6 1}$} & $\mathbf{1 9 7 1}$ & $\mathbf{1 9 8 1}$ & $\mathbf{1 9 9 1}$ & $\mathbf{2 0 0 2}$ \\
\hline Coefficient of old age \\
\hline Vojvodina population & 119.0 & 147.8 & 152.3 & 187.5 & 218.6 \\
\hline Yugoslav population & 79.7 & 74.6 & 83.9 & 95.5 & 137.2 \\
\hline Coefficient of youth & \multicolumn{7}{|c|}{} \\
\hline Vojvodina population & 332.3 & 300.2 & 267.5 & 257.1 & 226.4 \\
\hline Yugoslav population & 434.2 & 383.3 & 363.2 & 376.9 & 264.9 \\
\hline
\end{tabular}

Source: (Republic Statistical Office, 2003), (Federal Statistical Office, 1970), (Federal Statistical Office, 1974), (Provincial Statistical Office, 1982) and (Federal Statistical Office, 1993) 


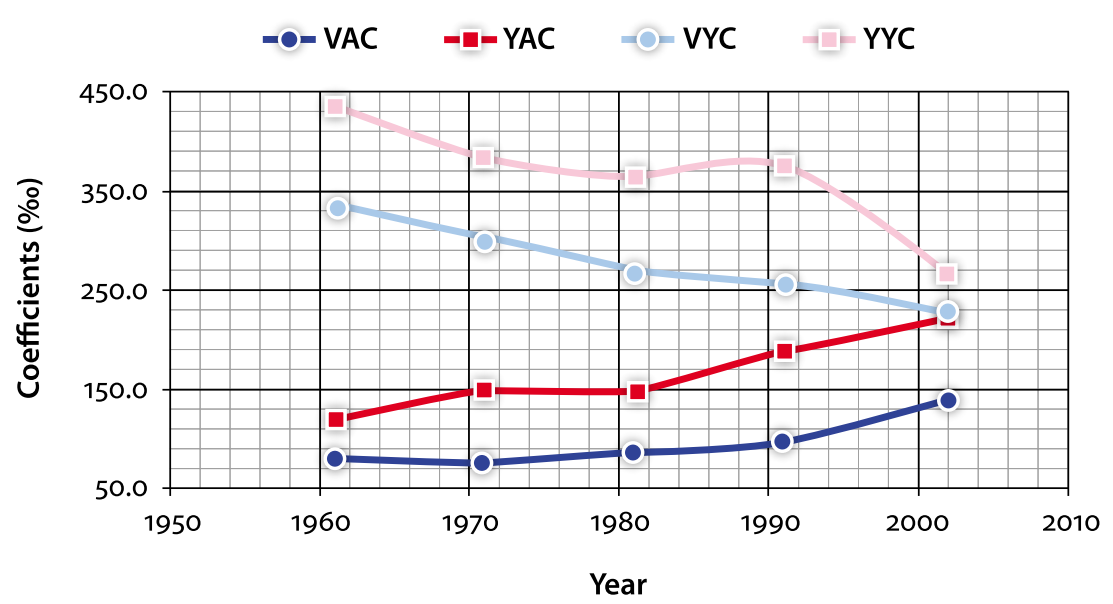

Graph 10 Coefficients of old and young age of Yugoslav population in Vojvodina (in $\%$ ), according to censuses 1961-2002

on Yugoslavs. In 2003, the term Yugoslavia ceased to be used. A Yugoslav, therefore, can be observed as the example of the evolution of one artificial nation.

\section{Acknowledgements}

The paper is part of the Project (Contract of the project: EBБ: 146017 "Demographic transitions in Serbia", financed by the Ministry of Science and Environment Protection

\section{References}

Breznik, D. 1980. Demografija, analiza, metodi i modeli, drugo izdanje, Naučna knjiga, Beograd.
Ministarstvo za ljudska i manjiska prava Srbije i Crne Gore 2004. Etnički mozaik Srbije, Prema podacima popisa 2002. godine, Beograd, pp. 426-427.

Rančić, M. 1980. Statistika stanovništva, Viša škola za primenjenu informatiku i statistiku, Odsek za statistiku, Beograd, pp.184-192.

Republički zavod za statistiku 2003. Stanovništvo, veroispovest, maternji jezik i nacionalna ili etnička pripadnost prema starosti i polu, podaci po opštinama, Popis stanovništva, domaćinstva i stanova u 2002, Republika Srbija, Beograd, pp. 24-25.

Savezni zavod za statistiku 1970. Vitalna, etnička i migraciona obeležja, Rezultati za republike i demografske rejone, Knjiga 1, Popis stanovništva, 1961, SFRJ, Beograd, pp. 22-23.

Savezni zavod za statistiku 1974. Stanovništvo, vitalna, etnička i migraciona obeležja, Rezultati po republikama i pokrajinama, Popis stanovništva i stanova 1971, SFRJ, Beograd, pp. 44.

Pokrajinski zavod za statistiku 1982. Stanovništvo, Osnovna obeležja po opštinama, Popis stanovništva, domaćinstava i stanova, 1981, SRS, SAP Vojvodina, Novi Sad, pp. 21-22.

Savezni zavod za statistiku 1993. Stanovništvo, nacionalna pripadnost, Podaci po opštinama, Popis '91, Savezna Republika Jugoslavija, Beograd, pp. 16. 